\title{
Review
}

\section{Beyond church and state: Democracy, secularism, and conversion}

\author{
Matthew Scherer \\ Cambridge University Press, Cambridge, 2013, x+240pp., \\ ISBN: 978-1-107-02609-4
}

Contemporary Political Theory (2016) 15, e1-e5. doi:10.1057/s41296-016-0076-9; published online 19 October 2016

There is a conventional story when it comes to secularism. It sets religion and politics apart in theory and practice so that, in Thomas Jefferson's classic image, a wall separates church and state. This formulation of conceptual and institutional differentiation is, in turn, compounded by a temporal division, which posits a historical rupture separating the religious "before" from the secular "now." Matthew Scherer argues in Beyond Church and State that this common account which he terms the "authorized view" of secularism - is partial and dissembling. Scherer distills his argument into three claims: first, the phenomenon of secularism is not fully captured by the "authorized view" that imagines a separation of religion and politics; second, secularism is in fact an ongoing process that transforms and transfigures religion and politics; and, third, this process of transformation is one of "crystalline conversion" (pp. 1-2).

The first two of these claims echo a now common refrain within the critical study of secularism. Indeed, Talal Asad proclaimed over a decade ago, "If anything is agreed upon, it is that a straightforward narrative progress from the religious to the secular is no longer acceptable" (2003, p. 1). Since the publication of Asad's Formations of the Secular, a growing consensus has formed around the idea that secularism does not simply signify the containment, decline, or absence of religion. The secular, in Asad's words, "is neither continuous with the religious that supposedly preceded it...nor a simple break from it (that is, it is not the opposite, an essence that excludes the sacred)" (2003, p. 24). Scholars such as William Connolly and Elizabeth Shakman Hurd built upon Asad's work by further interrogating secularism as a contingent constellation of discourses, institutions, and sensibilities that produce contestable conceptions of religion and its relationship to politics.

While the idea that secularism is not a simple break with the religious and that it is actually implicated in constituting what "religion" is may be familiar by this point, the core of Scherer's text - the figure of "crystalline conversion" - offers a

(c) 2016 Macmillan Publishers Ltd. 1470-8914 Contemporary Political Theory Vol. 15, 4, e1-e5 
strikingly original contribution. Admittedly, construing secularism through a figure so tied to the religious experience has a certain scandalous irony to it, yet it is exactly because of its religious association that the language of conversion offers an opportunity to re-think secularism apart from the impoverished field of concepts ("church" and "state") and narratives (religious decline and institutional differentiation) currently in play.

The language of conversion suggests an instantaneous transformation of the self. This "authorized" image maps conversion along a punctuated equilibrium model, with the conversion event marking the spontaneous and totalizing change from one fixed state to another. This model is exemplified in St. Augustine's Confessions, which seemingly conveys Augustine's smooth movement from sinner to faithful Christian. Yet in Scherer's careful parsing of Augustine, the elegance of this narrative obscures fugitive hesitations and omissions that haunt the margins of Augustine's text and bespeak the fraught, complex, and multifaceted process involved in "the formation of ethical subjects" (p. 44). Scherer's granular reading reveals the co-presence of two aspects of conversion: first, the sudden transformation present on the narrative surface, and second, the deeper, uneven, and incremental process of reshaping habits, sensibilities, and dispositions that precedes and lingers after the ostensible moment of conversion. Both these faces work together to constitute conversion, with the conventional narrative of immediate transformation crucial in terms of retrospectively consolidating identity. "Experience," Scherer writes, "feeds into narrative and narrative feeds back into experience. The process of conversion depends upon but exceeds its narrative representation" (p. 61).

Scherer fleshes out his theorization of conversion in Chapters Three and Five. In Chapter Three, he recovers and activates Henri Bergson's The Two Sources of Morality and Religion in order to conceptualize conversion as "the intersection of the divided tendencies of conservation and innovation inherent within life itself, at both an individual and a social level" (p. 112). Bergson captures this dynamic with the image of the crystalline structure, which evokes a substance "composed of layers that produce order and structure through the arrangement of planes and patterns within a homogenous physical structure" (p. 105). Crystalline structures give the appearance of transparent, stable wholes but are, in reality, sites of perpetual becoming and transformation where an assemblage of distinct composites, both old and new, interact and are reconfigured through time and creativity. In this way, Bergson's philosophy helps illuminate how "there is no dialectic, no negation, no emergence of one term from the other" when it comes to religion and secularism. "A modern secular age does not emerge from a break with the religious past," Scherer explains, "Rather, these 'ages' coexist as distinct and interlocking planes within a single crystalline structure" (p. 107).

These Bergsonian themes carry over into Chapter Five, where Scherer pivots to Stanley Cavell in order to articulate a practice of conversion fitting for democratic 
politics. As Scherer admits, this effort entails going "far beyond the task of reimagining secularism proposed by this book," but it suggests how the concept of conversion may be a useful figure for approaching diverse problems and dynamics in contemporary politics (p. 169). Scherer takes up Cavell's understanding of moral perfectionism, which Scherer characterizes as "shorthand for a continuous process of conversion," one that resists closure or the illusion of wholeness (p. 184). Central to this process are, on the one hand, the desire for a better life, and, on the other, a skeptical ethos that refuses certainty. Together, these open a sustained space for transformational experimentation.

In an appropriately crystalline manner, Scherer layers his concept-building chapters with interstitial analyses of two key figures in the authorized account of secularism. These readings of John Locke and John Rawls interrogate the micropolitics of their rhetorical performances, which are directed not merely at intellectual persuasion but at a deeper conversion of the audience. Scherer's provocative readings illuminate how these figures in the secular tradition do not reject a religious past but rather remain "locked in continuous and shifting patterns of interrelation with religion in the present" (p. 63). Scherer shows, for example, how Locke's A Letter Concerning Toleration, whose authorized surface stakes out a sharp analytical separation of the civil from the religious, employs rhetorical strategies that freely mix and interrelate religion and politics. In Scherer's compelling reading of Locke (which nicely complements Elizabeth Pritchard's similarly nuanced interpretation in Religion in Public: Locke's Political Theology), the Letter draws "theological-political resources" to discipline "dangerous dispositions and reformulate the patterns of sociability that sustain them" in order to form tolerant subjects (pp. 90-91). Locke attends most elaborately to the "dangerous dispositions" of pretense and zealotry, which are linked as pathologies of religion because of their common motivation for political power. Against these destabilizing formations, Locke cultivates an alternative manner of inhabiting religious faith that adheres to an ethos of "Peace, Equity, and Friendship" (quoted p. 90).

Scherer expands on these themes in Chapter Four when he turns his analytical attention to Rawls. According to this rhetorical analysis, Rawls's project to recodify the norms of argumentation operates not exclusively or even principally through its "authorized surface of contemporary secular discourse" and propositional reason and logic (p. 134). Instead this avowed reasoning is subtended and supplemented by what Scherer calls Rawls's "saintly measure," that is, the persuasive force of his righteous personal character and emotional appeals. These subtle rhetorical appeals manifest, for instance, in Rawls's prose, which folds in "passive voice, demonstrative sentences, myriad simple formulations, and careful arrangement of subsections" (p. 152). These techniques, along with Rawls's dogged disavowal of originality, produce a philosophical character of exemplary propriety and reasonableness that inclines readers toward its own performed model 
of reasonable conduct. Even if the characterization of Rawls's "saintliness" can at times come across as somewhat overdrawn, Scherer persuasively establishes how Rawls's political philosophy exceeds the register of propositional logic in order to inspire "the sense of justice" that is the necessary condition for the acceptance of the "principles of justice."

As this brief canvas suggests, Scherer's text offers a rich reconsideration of secularism through the figure of conversion. There is, of course, a risk that in attending so deeply and exclusively to works of political theory that the book forecloses consideration of the broader discursive and cultural field. In this sense, it mirrors the approach of works like Mark Lilla's The Stillborn God, which similarly privileges rarified philosophical discourses in its rendering of the hegemonic "authorized" narrative wherein secular rationality displaces political theology in Western thought. Scherer's book cleverly subverts this approach by reading the same texts, such as Locke's Letter, in a different register, but it also forces the analysis to focus on academic discourses rather than the broader and more diverse array of rhetorics and practices within the public sphere. If the objective is, as Scherer says, to "explain why we tend to imagine modern secularism in the way that we do" (p. 234), it seems necessary to either narrow this "we" to the small academic audience of these texts or expand analytical consideration to include nonacademic communities and the discourses circulating within them that might well engender competing conceptions of the religious and the secular.

The scope of the text is also limited when it comes to recent developments catalyzed by the so-called "religious revival." A growing body of theorists have responded to the religious resurgence of recent decades by rethinking the terms and practice of secularism. The very notion of a religious "revival" or "resurgence," of course, points to the residual power of the authorized narrative of secular modernity insofar as they imply that "the religious" was, for a moment, vanquished or quarantined. Yet the responses to this revival also mark the emergence of potential alternatives to the sharp separation model. How, then, might we interpret these phenomena with and through the figure of crystalline conversion? Is this just another episode in which fugitive hesitations and contradictions "beneath the elaborate concrete formations of modern secularism" (p. 233) are contested and reformed - that is, another reconfiguration of the "crystalline depths" that will leave the authorized form in place? Alternatively, are we in the midst of the formation of a new authorized narrative, one that revises and complicates - and perhaps displaces - the simple story of separation? Or, to be overly optimistic, might these developments signal a movement, however tentative, toward a more openly generous and protean - a more Bergsonian - form of life? If Scherer's text ultimately (and quite understandably) does not provide answers to such questions, it nonetheless revivifies and deepens the ways in which we can think about the past, present, and future of religion and politics. 


\section{Reference}

Asad, T. (2003). Formations of the secular: Christianity, Islam, modernity. Stanford, CA: Stanford University Press.

Brendan J. Wright

Princeton University, Princeton, NJ 08544, USA

bjwright@princeton.edu 